\title{
Effect of organic manures and rock phosphate on growth and yield of Bengal gram (Cicer arietinum L.)
}

\section{T. SARAVANAN AND P. PANNEERSELVAM}

Received : 21.08.2014; Revised : 01.10.2014; Accepted : 18.10.2014

\author{
MEMBERS OF RESEARCH FORUM: \\ Corresponding author : \\ T. SARAVANAN, Department of Crop \\ Management, Vanavarayar Institute of \\ Agriculture, Manakkadavu, POLLACHI \\ (T.N.) INDIA \\ Email: nrpads@hotmail.com \\ Co-authors : \\ P. PANNEERSELVAM, Department \\ of Crop Management, Vanavarayar \\ Institute of Agriculture, Manakkadavu, \\ POLLACHI (T.N.) INDIA \\ Email: paneerkvt@gmail.com
}

\section{Summary}

A field experiment was conducted on vertisolsat Natural Resources Protection and Development Society Research Station, Namakkal during Rabi season of 2012-13 and 2013-14 to study the effect of organic manure sand rock phosphate on growth and yield of Bengal gram (Cicer arietinum L.) in vertisols of Tamil Nadu. Significantly higher grain yield was recorded with rock phosphate application @ 200 kg/ha (2140 kg/ha) over $50 \mathrm{~kg}$ and 100 $\mathrm{kg}$ of rock phosphate per hectare except rock phosphate @ $150 \mathrm{~kg} / \mathrm{ha}(2069 \mathrm{~kg} / \mathrm{ha})$. Interaction effect of compost 5 t along with rock phosphate $200 \mathrm{~kg} / \mathrm{ha}$ recorded significantly higher grain yield $2130 \mathrm{~kg} / \mathrm{ha}$ ) and haulm yield $(3300 \mathrm{~kg} / \mathrm{ha})$ over other treatment combinations except either for organic manures FYM 5 to rcompost $5 \mathrm{t}$ along with 150 to $200 \mathrm{~kg}$ rock phosphate per ha. Significantly higher B:C ratio (3.32)was recorded with rock phosphate @ $200 \mathrm{~kg}$ / ha over other lower levels. Similarly, combination of compost @ $5 \mathrm{t} / \mathrm{ha}$ with $150 \mathrm{~kg}$ rock phosphate resulted in higher $\mathrm{B}: \mathrm{C}$ ratio (3.37).

Key words : Rock phosphate, Organic manures, Phosphate solubilising bacteria

How to cite this article : Saravanan, T. and Panneerselvam, P. (2014). Effect of organic manures and rock phosphate on growth and yield of Bengal gram (Cicer arietinum L.). Asian J. Soil Sci., 9(2): 203-207. 